\title{
EIGHT NEW SPECIES AND A NEW NAME IN THE GENUS ELATOSTEMA (URTICACEAE) ON MOUNT KINABALU, SABAH, MALAYSIA
}

\author{
REED S. BEAMAN \& NICOLETTA CELLINESE \\ Peabody Museum of Natural History, Yale University, 170 Whitney Avenue, \\ New Haven, CT 06520-8118, USA
}

\begin{abstract}
SUMMARY
The genus Elatostema J.R. Forst. \& G. Forst. (Urticaceae) is a large Palaeotropical group with perhaps 300 or more species. Eight new species are described here, six of which are endemic to Mt Kinabalu, and a new name is established.
\end{abstract}

Key words: Urticaceae, Elatostema, Mt Kinabalu, Sabah, Borneo, taxonomy.

\section{INTRODUCTION}

Mount Kinabalu is located near the northern tip of Borneo and is the tallest mountain in Southeast Asia between the Himalaya and New Guinea. With an elevation of 4,093.7 m, this isolated massif stands $1000 \mathrm{~m}$ taller than any other in Borneo. Elatostema species are abundant on Kinabalu in herbaceous undergrowth, especially along rivers and streams and near waterfalls. Some species occur on exposed ridges and slopes. There are 15 species of Elatostema on Mt Kinabalu previously published, and an additional eight species are newly described here. A revision of the genus on Mt Kinabalu is in preparation and will provide plates and photographs of all species.

\section{MATERIALS AND METHODS}

This work is based upon the study of herbarium specimens examined in and/or borrowed from the following herbaria: A, BM, FLAS, GH, K, L, MSC, NY, SAN, SING, UC, and US (Holmgren et al., 1990). Fieldwork was carried out on Mt Kinabalu by Reed Beaman during 1983-1984, 1995, and 1997. Measurements of the vegetative parts were taken from herbarium material and in the field whenever possible. Flowers and fruits were collected and stored in $70 \%$ alcohol, or, when fresh material was not available, they were taken from dried herbarium specimens, boiled and examined using a dissecting microscope. Data on the distribution and ecology were taken from specimen labels and personal observations in the field. The species represented here are based upon the concept of diagnosable entities, in which phylogenetic species represent the smallest discrete aggregation of sexual populations or asexual lineages. These were diagnosable by unique combinations of character states in comparable individuals (Nixon \& Wheeler, 1990). 


\section{DESCRIPTION OF TAXA}

\section{Elatostema auriculatifolium R.S. Beaman \& Cellin., spec.nov. - Map 1A}

Species E. penibukanensi affinis sed foliis magnis basi multo magis inaequalibus auricula singulari quadrinervia differt. - Typus: Clemens 32374 (holo BM; iso GH, NY), above Marai Parai, $2700 \mathrm{~m}$.

Fleshy herbs, over $1 \mathrm{~m}$ tall, dioecious. Stems \pm terete or slightly square, portions bearing leaves $2-4 \mathrm{~mm}$ diam., glabrous. Leaves alternate, $7.1-11.2$ by $2.3-3.9 \mathrm{~cm}$, subcoriaceous to coriaceous, venation asymmetrical, brochidodromus, adaxial surface with conspicuous pellucid dots, cystoliths lacking, abaxial surface glabrous, cystoliths elongate or spheroidal, conspicuous along veins, in the interstices between tertiary veins. Petioles 1-2 mm long, with conspicuous, elongate cystoliths, base strongly oblique, rounded to auriculate, apex acute or acuminate, margins crenulate, hydathode present. Stipules $14-21$ by 2-4 mm , narrowly ovate or spathulate, membranaceous, apex acute or obtuse, often apiculate. Inflorescences axillary, almost always unisexual, many flowered cymes or involucrate heads or disks. Staminate inflorescences long pedunculate, involucrate heads, subtended by a pair of large involucral bracts opposite one another, and fused at the margins, forming a broad flattened disk. Pistillate inflorescences sessile, fasciculate with bracts free, lacking cystoliths, apex corniculate with a callus. Staminate flowers 1.1-1.4 mm across at anthesis, sessile or borne on a pedicel to c. $1 \mathrm{~mm}$ long, in some cases elongating at anthesis to $3-4 \mathrm{~mm}$, tepals 5, free, glabrous, hooded, white, or occasionally tinged with red, apex apiculate, stamens 5. Pistillate flowers \pm sessile, radially symmetrical, tepals 3 or 4 , free, triangular, not exceeding the staminodia. Achenes obovoid, c. 1.5 by $0.9 \mathrm{~mm}$, slightly roughened, reddish.

Distribution - Known only from Mt Kinabalu.

Habitat - Upper montane mossy forest, near granite wall. Elevation 2100 -3000 m.

Note - No other species of Elatostema from Kinabalu has such distinctively shaped leaves. The two sides of the leaf base differs by as much as $1 \mathrm{~cm}$ along the petiole, and four secondary veins branch from the midrib into the auriculum. This species is closely related to E. penibukanense, but the leaves are larger and less symmetrical.

Additional material examined:

Beaman, R.S. 1303 (FLAS); Clemens 31904 (GH), 33128 (BM), 33845 (BM, GH, NY), 35100 (BM), 50984 (BM, K, NY).

\section{Elatostema bullatum R.S. Beaman \& Cellin., spec. nov. - Map 1B}

Folia saepe bullata; species E. macrophyllo similis sed pagina folii superiore pilis glanduliferis pubescenti differt; capitula mascula subdiscoidea rectangularia. - Typus: Clemens 26524 (holo BM; iso GH, K, L, UC), Dallas, 900 m.

Large, suffrutescent herbs, 60-90 cm tall, prostrate at the base, monoecious. Stems \pm terete or slightly quadrangular, portions bearing leaves $3-5 \mathrm{~mm}$ diam., with two longitudinal grooves on opposite faces of internode, positioned $90^{\circ}$ from attachment of leaf or leaves of adjacent upper node, with conspicuous fusiform or \pm cylindrical, straight to slightly curved cystoliths, pubescent. Leaves anisophyllous, but with the smaller of the pair often deciduous or difficult to detect, the larger $9-13.5$ by (2.7-)3.5-5.8(-6.3) $\mathrm{cm}$, asymmetrical, bullate, venation asymmetrical, camptodromus on one side of the 
midvein and brochidodromus on the other, adaxial surface with glandular-based hairs present throughout, cystoliths present, abaxial surface pubescent along midvein, secondary, and tertiary veins, cystoliths elongate, conspicuous along veins, in the interstices between tertiary veins, base oblique, rounded to auriculate, apex acute or acuminate, margins serrate, ciliate, teeth terminating with a conspicuous hair, hydathode present. Petioles $0.5-4 \mathrm{~mm}$ long. Stipules $18-27$ by $0.8-2.5 \mathrm{~mm}$, narrowly ovate or spathulate, membranaceous, apex acute or obtuse, often apiculate. Inflorescences axillary, almost always unisexual, many flowered involucrate heads or disks. Staminate inflorescences short pedunculate, involucrate heads, distinctly ordered into squarose compartments, subtended by a pair of large involucral bracts opposite one another, and fused at the margins, forming a broad flattened disk. Pistillate inflorescences sessile, fused into an involucrate disk, bracts indistinct and often fused, apex acute, obtuse or rounded, with cystoliths on the abaxial surface. Staminate flowers $0.8-1.2 \mathrm{~mm}$ across at anthesis, sessile or borne on a pedicel to c. $1 \mathrm{~mm}$ long, in some cases elongating at anthesis to 3-4 mm, tepals 4, free, glabrous, ovate, white, or occasionally tinged with red, apex rounded, stamens 4 . Pistillate flowers \pm sessile, slightly bilaterally symmetrical, tepals 3 , free, triangular, not exceeding the staminode. Achenes obovoid, $0.3-0.5$ by $0.16-0.3$ $\mathrm{mm}$, ribbed longitudinally, reddish.

Distribution - Mt Kinabalu and other areas in Sabah.

Habitat - Hill forest, lower montane forest, at base of waterfalls and along streams. Elevation 700-900 m.

Note - This is one of the few species known from elevations below $900 \mathrm{~m}$ on Mt Kinabalu. The leaves are among the largest in the Kinabalu species, and are often very strongly bullate, densely packed with cystoliths on the adaxial surface, and covered with setose, glandular based hairs. The staminate inflorescences are extensively organized into rectangular compartments of cymose derivation.

Additional material examined:

Aban Gibot SAN 55405 (K); Amin \& Suin SAN 123401 (K); Beaman 10928 (K); Chew, Corner \& Stainton 127 (K, L, SING), 1504 (GH, K, L, NY, SING); Clemens 26024 (BM); Clemens, M.S. 10403 (UC).

\section{Elatostema dallasense R.S. Beaman \& Cellin., spec. nov. - Map 1C}

Pagina folii superior ad basim pilis glanduliferis sparsim obsita et cystolithis minutis punctiformibus atque breviter linearibus albidis quaquaversum directis instructa; capitula feminea caespitosa, caespitum marginibus et apicibus bractearum pilis translucidis praeditis. - Typus: Clemens 26053 (holo BM), Dallas, $900 \mathrm{~m}$.

Suffrutescent herbs, $30-110 \mathrm{~cm}$ tall, dioecious. Stems \pm terete or slightly quadrangular, portions bearing leaves $2-4 \mathrm{~mm}$ diam., with two longitudinal grooves on opposite faces of internode, positioned $90^{\circ}$ from attachment of leaf or leaves of adjacent upper node, with conspicuous fusiform or \pm cylindrical, straight to slightly curved cystoliths, pubescent. Leaves sessile, anisophyllous, but with the smaller of the pair often deciduous or difficult to detect, the larger $(4.5-) 6-9(-12)$ by $(2.5-) 3-4(-5.5) \mathrm{cm}$, subcoriaceous to coriaceous, venation asymmetrical, camptodromus on one side of the midvein and brochidodromus on the other, adaxial surface with glandular-based hairs present throughout, cystoliths present, oriented radially around glandular hairs or 

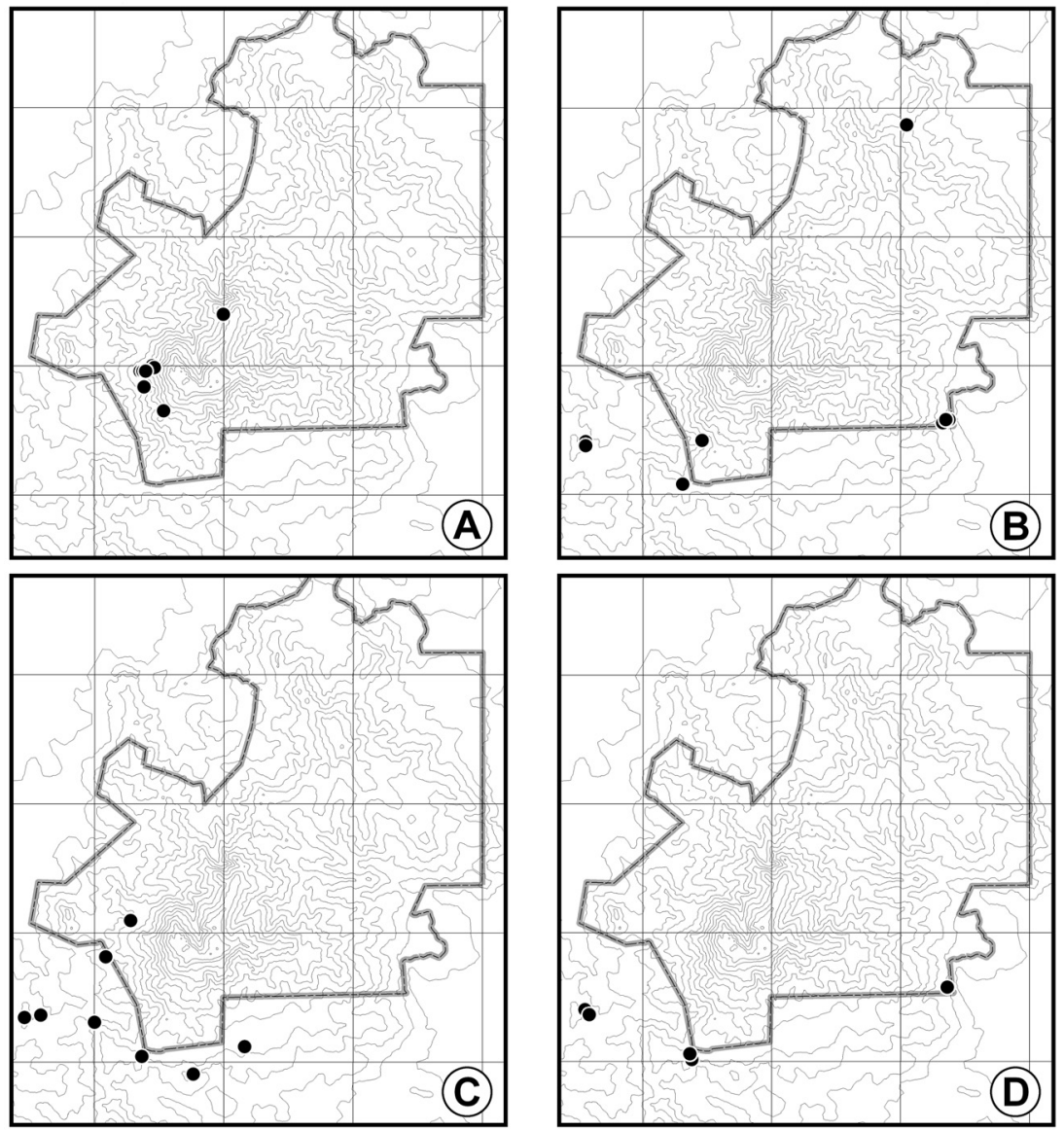

Map 1. Distribution of A: Elatostema auriculatifolium R.S. Beaman \& Cellin.; B: E. bullatum R.S. Beaman \& Cellin. (on Kinabalu); C: E. dallasense R.S. Beaman \& Cellin.; D: E. flavovirens R.S. Beaman \& Cellin. The Kinabalu Park boundary and $250 \mathrm{~m}$ contours are also shown.

pellucid dots, abaxial surface pubescent along midvein, secondary, and tertiary veins, and in the interstices between the tertiary veins, cystoliths elongate, conspicuous along veins, in the interstices between tertiary veins, base oblique, rounded to auriculate, apex acute or acuminate, margins serrate, ciliate, teeth terminating with a conspicuous hair. Stipules (4.5-)6-8(-10) by $2-4 \mathrm{~mm}$, narrowly ovate or spathulate, membranaceous, apex acute or obtuse, often apiculate. Inflorescences axillary, almost always unisexual, many flowered involucrate heads or disks. Staminate inflorescences short pedunculate, involucrate heads, distinctly ordered into squarose compartments, subtended by a pair of large involucral bracts opposite one another. Pistillate inflorescences sessile, fused into an involucrate disk, bracts indistinct and often fused, apex acute, obtuse or rounded, with cystoliths on the abaxial surface. Staminate flowers $0.8-1.2 \mathrm{~mm}$ across at anthesis, sessile or borne on a pedicel to c. $1 \mathrm{~mm}$ long, in some cases elongating at anthesis to 3-4 mm, tepals 4, free, sparsely ciliate on the abaxial surface and margins 
near the apex, hooded, white, or occasionally tinged with red, apex callused, stamens 4 . Pistillate flowers \pm sessile, slightly bilaterally symmetrical, tepals 3 , free, triangular, not exceeding the staminode. Achenes obovoid, $0.7-0.9$ by $0.3-0.4 \mathrm{~mm}$, reddish.

Distribution - Known only from Mt Kinabalu.

Habitat - Hill forest, lower montane forest, in ravines along small streams. Elevation $900-1500 \mathrm{~m}$.

Note - This species is named for the place where Mary and Joseph Clemens lived for about four months while collecting plants on Mt Kinabalu. Their collections of vascular plants made in 1915 and from 1931-1933 are the most extensive for the mountain. This species is one of the few that have punctiform cystoliths on the adaxial leaf surface. The white tufted pistillate inflorescences are also distinctive.

Additional material examined:

Chew \& Corner 7106 (K, SING); Chew, Corner \& Stainton 65 (K,L); Clemens 26805 (BM, K, UC), 28208 (BM, NY, UC), 30361 (K, UC), 31564 (BM), 33080 (BM, GH); Meijer SAN 27669 (K, L).

\section{Elatostema flavovirens R.S. Beaman \& Cellin., spec. nov. - Map 1D}

Species E. acuminato similis sed foliis in sicco flavovirentibus et pagina superiore pubescenti ad basim pilis glanduliferis breviter sparsimque obsita et cystolithis albidis linearibus vel curvatis quaquaversum directis praedita, differt. - Typus: Clemens 30358 (holo GH; iso K), Dallas, $900 \mathrm{~m}$.

Herbs, 24-50 cm tall, dioecious. Stems green, \pm terete or slightly quadrangular, portions bearing leaves 1-3 mm diam., with two longitudinal grooves on opposite faces of internode, positioned $90^{\circ}$ from attachment of leaf or leaves of adjacent upper node with conspicuous fusiform or \pm cylindrical, straight to slightly curved cystoliths, pubescent. Leaves anisophyllous, but with the smaller of the pair often deciduous or difficult to detect, the larger (1.5-)2-6(-8) by $(0.7-) 1-1.5(-2.5) \mathrm{cm}$, asymmetrical, membranaceous, venation asymmetrical, camptodromus on one side of the midvein and brochidodromus on the other, adaxial surface with glandular-based hairs present throughout, cystoliths present, abaxial surface pubescent along midvein, secondary, and tertiary veins, cystoliths elongate, conspicuous along veins, in the interstices between tertiary veins, base oblique, acute or cuneate, apex acute or acuminate, margins serrate, ciliate, teeth terminating with a conspicuous hair, hydathode present. Petioles 1-4 mm long, pubescent, with conspicuous, elongate cystoliths. Stipules (2.5-)4-6(-8) by $0.5-2 \mathrm{~mm}$, narrowly ovate or spathulate, membranaceous, apex acute or obtuse, often apiculate. Inflorescences axillary, almost always unisexual, many flowered cymes or involucrate heads or disks. Staminate inflorescences, subtended by a pair of large involucral bracts opposite one another. Pistillate inflorescences sessile, fused into an involucrate disk, bracts indistinct and often fused, with a keeled midrib, apex corniculate, lacking cystoliths. Staminate flowers $0.8-1.2 \mathrm{~mm}$ across at anthesis, sessile or borne on a pedicel to c. $1 \mathrm{~mm}$ long, in some cases elongating at anthesis to $3-4 \mathrm{~mm}$, tepals 4, free, white, or occasionally tinged with red, stamens 4. Pistillate flowers \pm sessile, slightly bilaterally symmetrical, tepals 3 , free, linear, exceeding staminodia, staminodia 3 or 4 . Achenes obovoid, $0.4-0.6$ by $0.2-0.4 \mathrm{~mm}$, ribbed longitudinally, reddish.

Distribution - Known only from Mt Kinabalu. It is locally common in the few localities from which it has been recorded. 
Habitat - Disturbed slopes and road cuts in hill forest and lower montane forest. Elevation $700-1500 \mathrm{~m}$.

Note - This species is distinct from other Elatostema from Kinabalu in the yellowgreen color of the dried leaves. A diagnostic character not inherent in the plant is that almost all specimens exhibit extensive insect predation.

Additional material examined:

Chew, Corner \& Stainton 1502 (K, L); Clemens s.n.(BM), 26653 (BM, GH, K, NY, UC), 26653 A $(\mathrm{GH}, \mathrm{K})$.

\section{Elatostema maraiparaiense R.S. Beaman \& Cellin., spec. nov. - Map 2A}

A ceteris speciebus generis pagina folii superiore foveolata cystolithis carentibus; capitula caespitosa, caespitum marginibus et apices bractearum pilis translucidis obsitis differt.

- Typus: Clemens 32373 (holo BM; iso GH, NY), Marai Parai Spur, $1500 \mathrm{~m}$.

Epiphytic root climbers, 0.6-3 m or higher, dioecious. Stems \pm terete or slightly square, portions bearing leaves $3-5 \mathrm{~mm}$ diam., glabrous or pubescent, cystoliths lacking. Leaves anisophyllous, but with the smaller of the pair often deciduous or difficult to detect, the larger (4-) $9.3-16.5$ by (2.5-) $2.9-5.8 \mathrm{~cm}$, (weakly) asymmetrical, membranaceous, venation asymmetrical, camptodromus on one side of the midvein and brochidodromus in the distal half on the other, adaxial surface, cystoliths present, abaxial surface glabrous or pubescent along midvein, secondary, and tertiary veins, and often in the interstices between the tertiary veins, cystoliths lacking, base oblique, acute or cuneate, apex acute or acuminate, margins entire or crenulate, teeth terminating with a conspicuous hair, hydathode present. Petioles $2-6 \mathrm{~mm}$ long, pubescent. Stipules $3-15$ by $0.4-1 \mathrm{~mm}$, narrowly ovate or spathulate, membranaceous, apex acute or obtuse, often apiculate. Inflorescences axillary, almost always unisexual, many flowered cymes or involucrate heads or disks. Staminate inflorescences, involucrate heads, subtended by a pair of large involucral bracts opposite one another. Pistillate inflorescences short pedunculate, sessile, fused into an involucrate disk, bracts indistinct and often fused. Staminate flowers $1.1-1.4 \mathrm{~mm}$ across at anthesis, sessile or borne on a pedicel to c. $1 \mathrm{~mm}$ long, in some cases elongating at anthesis to $3-4 \mathrm{~mm}$, tepals 4 or 5, free, sparsely ciliate on the abaxial surface and margins near the apex, elliptic, white, or occasionally tinged with red, apex rounded, stamens 4 or 5 . Pistillate flowers \pm sessile, slightly bilaterally symmetrical, tepals 3-5, free, not exceeding the staminodia. Achenes obovoid, c. 0.5 by $1 \mathrm{~mm}$, reddish.

Distribution - Known only from Mt Kinabalu.

Habitat - In montane ultramafic forest along river margins. Elevation 900-2100 m.

Note - Elatostema maraiparaiense is named for Marai Parai on the west side of Mt Kinabalu, where the wet ultramafic soils contribute to a sedge-dominated meadow of Costularia pilisepala surrounded by a forest of dwarfed trees and shrubs. The area is noted for endemic taxa in many families, which occur predominantly on ultramafic substrates. This species is known only from ultramafic localities on Mt Kinabalu as well as from Tenompok. The adaxial surface of the leaves of this species lack pubescence and cystoliths, but have minute pits. The staminate inflorescences appear as white tufts owing to copious translucent hairs on the margins and apices of the inflorescence bracts. 
Additional material examined:

Clemens s.n.(A), 28944 (BM, GH, K, NY, SING, UC), 29386 (BM, GH, K, UC), 29400 (BM, K, UC), $29400 A$ (GH, K, UC), 30364 (GH), 32606 (BM, NY), 32945 (GH, NY), $33080 A(\mathrm{BM}), 34239$ (BM), 40302 (BM, K, NY); Nooteboom \& Aban 1550 (L).

\section{Elatostema pinnativenium R.S. Beaman \& Cellin., spec. nov. - Map 2B}

A ceteris speciebus generis pagina foliis pluripinnativenis venatione craspedodroma differt; capitula mascula subdiscoidea rectangularia. - Typus: Chew \& Corner 4021 (holo A; iso K, L, SING), Mesilau River, 1500 m.

Fleshy, suffrutescent herbs to $1.24 \mathrm{~m}$ high, monoecious and dioecious. Stems \pm terete or slightly square, portions bearing leaves $3-5 \mathrm{~mm}$ diam., with two longitudinal grooves on opposite faces of internode, positioned $90^{\circ}$ from attachment of leaf or leaves of adjacent upper node, pubescent, cystoliths lacking. Leaves anisophyllous, but with the smaller of the pair often deciduous or difficult to detect, the larger 11.2-23.2 by 4.2-7.6 $\mathrm{cm}$, asymmetrical, subcoriaceous, coriaceous, or fleshy, venation craspedodromus, adaxial surface, cystoliths present or occasionally lacking, abaxial surface pubescent along midvein, secondary, and tertiary veins, and densely in the interstices between the tertiary veins, cystoliths elongate, occasionally along veins, in the interstices between tertiary veins, base equal or oblique, acute or cuneate, apex acute or acuminate, margins entire or somewhat serrate, ciliate, teeth terminating with a conspicuous hair, hydathode present. Petioles $3-11 \mathrm{~mm}$ long, pubescent. Stipules $24-46$ by $0.8-3.5 \mathrm{~mm}$, narrowly ovate or spathulate, membranaceous, apex acute or obtuse, often apiculate. Inflorescences axillary, almost always unisexual, many flowered involucrate heads or disks. Staminate inflorescences sessile, involucrate heads, distinctly ordered into squarose compartments, subtended by a pair of large involucral bracts opposite one another. Pistillate inflorescences sessile, fused into an involucrate disk, bracts indistinct and often fused, apex acute, obtuse or rounded, lacking cystoliths. Staminate flowers 1.1-1.4 $\mathrm{mm}$ across at anthesis, sessile or borne on a pedicel to c. $1 \mathrm{~mm}$ long, in some cases elongating at anthesis to $3-4 \mathrm{~mm}$, tepals 4 , free, occasionally sparsely ciliate on the abaxial surface and margins near the apex, obovate, white, or occasionally tinged with red, apex long apiculate, stamens 4. Pistillate flowers \pm sessile, slightly bilaterally symmetrical, tepals 3 , free, triangular, not exceeding the staminodia. Achenes obovoid, $0.5-0.8$ by $0.15-0.25 \mathrm{~mm}$, reddish, slightly roughened.

Distribution - Known only from Mt Kinabalu.

Habitat - Hill forest and lower montane forest on steep wet slopes and on rocks along streams and near springs. Elevation 800-1500 m.

Note - Elatostema pinnativenium is the only species of the genus from Mt Kinabalu with strongly pinnate leaf venation, and is therefore well marked. It is also one of the largest species, especially in the size of the leaves.

Additional material examined:

Beaman 10601 (MSC); Chew \& Corner 4009 (K), 4578 (K, L), 4849 (K, L, SING); Clemens s.n. (BM) 900 m, s.n. (BM) 1500 m, 26054 (BM, L), 26187 (A, BM), 26260 bis (BM, K), 26594 (BM, GH, K, NY, SING, UC), 30332 (K), 30357 (K); Cockburn 70109 (SAN); Daim Andau 362 (K); Hou 299 (L); Kanis SAN 51479 (K, SING). 

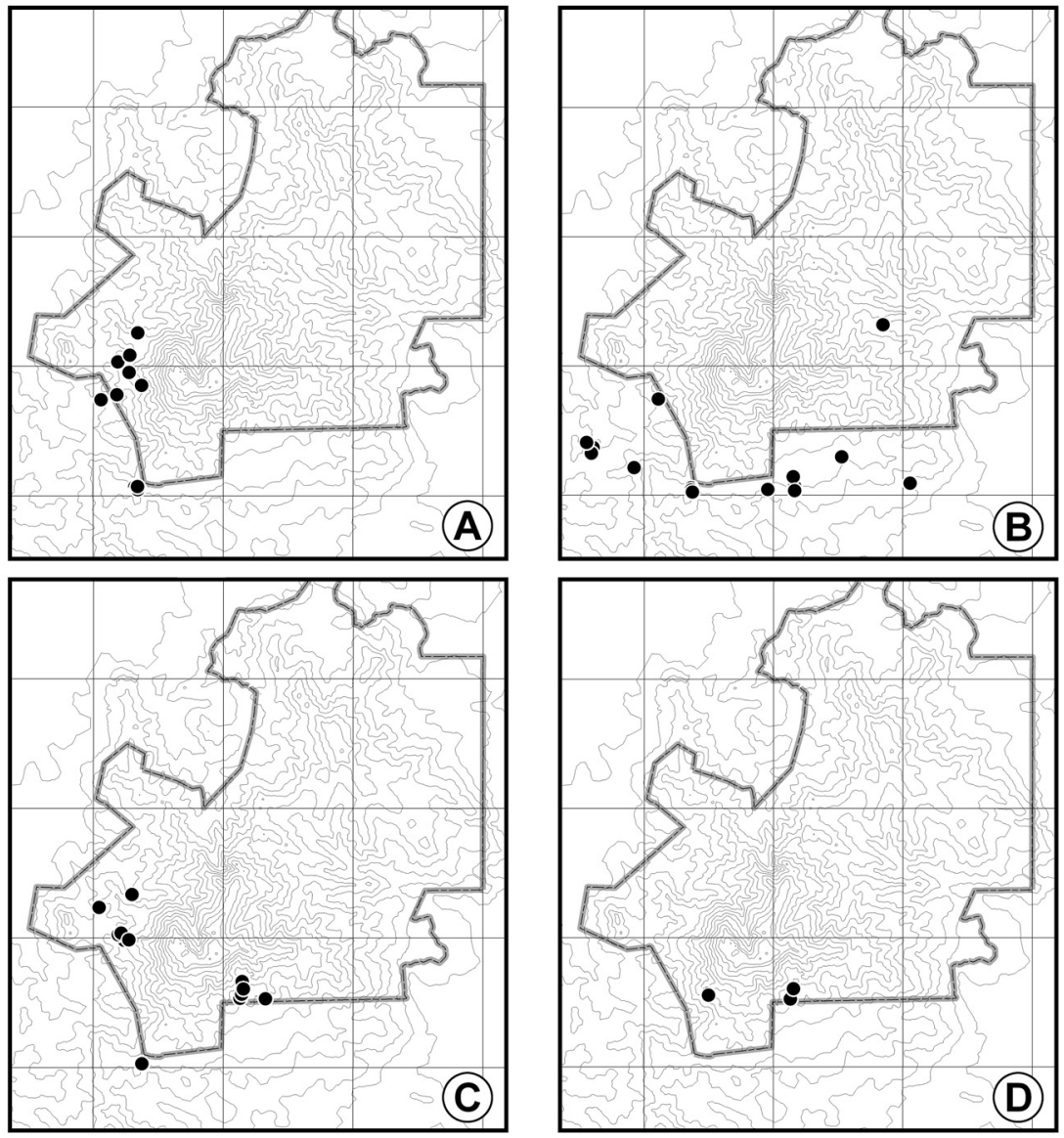

Map 2. Distribution of A: Elatostema maraiparaiense R.S. Beaman \& Cellin.; B: E. pinnativenium R.S. Beaman \& Cellin.; C: E. purpurascens R.S. Beaman \& Cellin.; D: E. serpentinicola R.S. Beaman \& Cellin. The Kinabalu Park boundary and $250 \mathrm{~m}$ contours are also shown.

\section{Elatostema purpurascens R.S. Beaman \& Cellin., spec.nov. - Map 2C}

Species E. kinabaluensi affinis sed foliis supra cystolithis albidis creberrimis linearibus quaquaversum directis praeditis in sicco non nigrescentibus differt. - Typus: R.S. Beaman 1256 (holo FLAS; iso GH, SAN, YU), Marai Parai Spur, 1800-2000 m.

Small, erect herbs, undersides of young leaves purple, appearing somewhat glaucous when dried, monoecious. Stems purple, \pm terete or slightly quadrangular, portions bearing leaves 1-2 $\mathrm{mm}$ diam., with two longitudinal grooves on opposite faces of internode, positioned $90^{\circ}$ from attachment of leaf or leaves of adjacent upper node, pubescent, cystoliths lacking. Leaves anisophyllous, but with the smaller of the pair often deciduous or difficult to detect, the larger $1.1-2.8$ by $0.4-0.8 \mathrm{~cm}$, subcoriaceous to coriaceous, venation asymmetrical, camptodromus on one side of the midvein and brochidodromus in the distal half on the other, adaxial surface with glandular-based hairs present throughout, cystoliths present, abaxial surface pubescent along midvein, 
secondary, and tertiary veins, cystoliths elongate, conspicuous along veins, in the interstices between tertiary veins, base oblique, acute or cuneate, apex acute or acuminate, margins serrate, ciliate, teeth terminating with a conspicuous hair. Petioles $1-2 \mathrm{~mm}$ long. Stipules $1-2$ by $0.2-0.4 \mathrm{~mm}$, narrowly ovate or spathulate, membranaceous, apex acute or obtuse, often apiculate. Inflorescences axillary, almost always unisexual, many flowered involucrate heads or disks. Staminate inflorescences long pedunculate, involucrate heads, subtended by a pair of large involucral bracts opposite one another and fused at the margins, forming a broad flattened disk. Pistillate inflorescences sessile, fused into an involucrate disk, bracts indistinct and often fused, occasionally with a keeled midrib, apex acute, obtuse or rounded with callus. Staminate flowers 1.1-1.4 $\mathrm{mm}$ across at anthesis, sessile or borne on a pedicel to c. $1 \mathrm{~mm}$ long, in some cases elongating at anthesis to 3-4 $\mathrm{mm}$, tepals 4 , free, elliptic, sparsely ciliate on abaxial surface and margins near the apex, white, or occasionally tinged with red, apex callused and apiculate, stamens 4 . Pistillate flowers \pm sessile, slightly bilaterally symmetrical, tepals 3 , exceedingly reduced, not exceeding the staminodia. Achenes obovoid, $0.5-1$ by $0.2-0.3 \mathrm{~mm}$, ribbed longitudinally, reddish.

Distribution - Known only from Mt Kinabalu.

Habitat - This species occurs mostly on ultramafic habitats in hill forest and lower to mid-montane forest, on rocks and boulders near streams and waterfalls. Elevation $1100-2400 \mathrm{~m}$.

Note - Much of the plant surface of this species is tinged with purple, particularly the abaxial leaf surface, the stems, and the apices of the tepals. The leaves often appear somewhat glaucus below. The leaf shape in this species is very similar to that of E. kinabaluense, but the adaxial leaf surface is always densely clothed with cystoliths and is never bullate. The species is more widespread than E. kinabaluense, but has not been collected from Penibukan Ridge.

Additional material examined:

Beaman, R.S. 804 (FLAS), 1257 (FLAS), 1269 (FLAS), 1325 (FLAS), 1332 (FLAS); Chew \& Corner 4808 (K, SING); Clemens 28739 (BM, GH, K, UC), 29078 (BM, GH, K, UC), 32574 (BM, GH, NY), 35097 (BM), 40020 (BM, NY, UC); Clemens, M.S. 10979 (UC).

\section{Elatostema serpentinicola R.S. Beaman \& Cellin., spec. nov. - Map 2D}

Species E. tenompokensi similis sed foliis succulentis supra cystolithis albidis fusiformibus creberrimis quaquaversum directis praeditis differt. - Typus: R.S. Beaman 1292 (holo FLAS), Gurulau Spur, 2400 m.

Fleshy herbs, $15-40 \mathrm{~cm}$ tall, dioecious. Stems green, \pm terete or slightly quadrangular, portions bearing leaves $1-3 \mathrm{~mm}$ diam., with two longitudinal grooves on opposite faces of internode, positioned $90^{\circ}$ from attachment of leaf or leaves of adjacent upper node, usually with conspicuous fusiform, or \pm cylindrical, straight to slightly curved cystoliths, pubescent. Leaves sessile, anisophyllous, but with the smaller of the pair often deciduous or difficult to detect, the larger (1.6-) 2.5-5.5(-6.1) by $(0.8-) 1.4-1.8(-2.7)$ $\mathrm{cm}$, asymmetrical, slightly fleshy, venation asymmetrical, brochidodromus, adaxial surface with glandular-based hairs present throughout, cystoliths present, abaxial surface pubescent along midvein, secondary, and tertiary veins, and often in the interstices between the tertiary veins, cystoliths elongate, conspicuous along veins, in the interstices between tertiary veins, base oblique, acute, cuneate, rounded or auriculate, apex acute 
or acuminate, margins serrate, hydathode present. Stipules $0.2-0.5$ by $0.3-0.7 \mathrm{~mm}$, narrowly ovate or spathulate, membranaceous, apex acute or obtuse, often apiculate. Inflorescences axillary, almost always unisexual, many flowered involucrate heads or disks. Staminate inflorescences long pedunculate, involucrate heads, subtended by a pair of large involucral bracts opposite one another, and fused at the margins, forming a broad flattened disk. Pistillate inflorescences sessile, fused into an involucrate disk, bracts indistinct, with corniculate apices and cystoliths on abaxial surface. Staminate flowers $0.7-0.8 \mathrm{~mm}$ across at anthesis, sessile or borne on a pedicel to c. $1 \mathrm{~mm}$ long, in some cases elongating at anthesis to 3-4 mm, tepals 4, free, glabrous, hooded, white, or occasionally tinged with red, apex apiculate, stamens 4. Pistillate flowers \pm sessile, slightly bilaterally symmetrical, tepals 3 or 4 , free, truncate, not exceeding the staminode. Achenes obovoid, c. 0.5 by $0.2 \mathrm{~mm}$, ribbed longitudinally, reddish.

Distribution - Known only from Mt Kinabalu.

Habitat - In upper montane mossy elfin cloud forest. In gullies and on boulders in stream beds. Elevation 1500-2900 m.

Note - This is one of the high elevation endemics, and is known from ultramafic substrates, although its occurrence on the Eastern Ridge suggests that it is not restricted to ultramafics. The species is distinct from the other high elevation species in its very erect herbaceous habit. As in E. bulbothrix, the adaxial leaf surfaces are densely covered with cystoliths.

Additional material examined:

Chew \& Corner 4837 (K, SING); Chew, Corner \& Stainton 943 (K, L, SING); Clemens 29817 (BM), $51074(\mathrm{BM}, \mathrm{K}, \mathrm{L}, \mathrm{NY}), 51650(\mathrm{BM})$.

\section{Elatostema gibbsiae R.S. Beaman, nom. nov.}

Elatostema viridissimum Gibbs (1914) 141, non E. viridissimum Rech. (1908) 49. -Type: Gibbs 4054 (holo BM), Penibukan, $1800 \mathrm{~m}$.

Note - The name E. gibbsiae is used in tribute to Lilian Gibbs (1870-1925), who first discovered and described the species. The bright green leaves of this species remain so after drying, making it very attractive even on the herbarium sheet.

\section{ACKNOWLEDGEMENTS}

We are very grateful to Mark Coode (K) for editing the Latin diagnoses. In addition, we want to express our gratitude to John Beaman and Walter Judd who have provided invaluable intellectual support throughout the years.

\section{REFERENCES}

Gibbs, L. 1914. A contribution to the flora and plant formations of Mount Kinabalu and the highlands of British North Borneo. J. Linn. Soc. Bot. 42: 1-240.

Holmgren, P.K., N.H. Holmgren \& L.C. Barnett. 1990. Index Herbariorum. Part 1. The herbaria of the world (8th ed.). New York Botanical Garden, Bronx, NY.

Nixon, K.C. \& Q.D. Wheeler. 1990. An amplification of the phylogenetic species concept. Cladistics 6: 211-213.

Rechinger, K. 1908. Plantae novae pacificae. Feddes Repert. Spec. Nov. Regni Veg. 6: 49. 